Article

\title{
Detection of Karst Features in the Black Hills Area in South Dakota/Wyoming, USA, Based on Evaluations of Remote Sensing Data
}

\section{Barbara Theilen-Willige}

Institute of Applied Geosciences, TU Berlin, Ernst Reuter Platz 1, 10587 Berlin, Germany; Barbara.Theilen-Willige@campus.tu-berlin.de or Barbara.Theilen-Willige@t-online.de; Tel.: +49-7771-1868

Received: 3 April 2018; Accepted: 11 May 2018; Published: 28 May 2018

\begin{abstract}
Landsat 8, Sentinel 2, Aster, RapidEye and PlanetScope data and Sentinel 1- and Advanced Land Observing Satellite (ALOS)-Phased Array type L-band Synthetic Aperture Radar (PALSAR)-radar images have been evaluated for a karst feature inventory in the Black Hills area in Wyoming/South Dakota, USA. The GeoInformation System (GIS) integrated evaluation of the different satellite data included as well World Imagery files of ESRI and Bing Maps high resolution satellite data of Microsoft. The satellite data revealed several types of circular features related to karst such as enclosed depressions and collapsed dolines as well as traces of tectonic/structural features (visualized by lineament analysis) cutting through youngest sediments, influencing karstification processes. The origin of the circular features is complex and partly unknown, needing further investigations. Digital Elevation Model (DEM) data, such as Aster- and Shuttle Radar Topography Mission (SRTM) DEM data with $30 \mathrm{~m}$ and ALOS PASAR DEM with $12.5 \mathrm{~m}$ spatial resolution contributed to the detection of depressions, partly related to karst phenomena (sinkholes). Time series of satellite data reveal seasonal changes of the landscape and provide a data base for the documentation of the impact of climate change.
\end{abstract}

Keywords: karst; Black Hills; USA; remote sensing; GIS

\section{Introduction}

The geologic investigation of the Black Hills in Wyoming/South Dakota dates back to the 19th century [1-3]. Since the availability of satellite data, additional/new geologic knowledge-input was possible, especially since 2015, when satellite data such as Sentinel and Aster became free available like Landsat data. This study aims to carry out a comparative and aggregating analysis of these satellite data in order to gain additional knowledge about the complex, geologic structure of the Black Hills, especially related to karst phenomena. Karst features such as dolines vary in their morphology and origins as there are collapse dolines and enclosed depressions. Solution cavities can exhibit large short-term variability in hydrogeologic characteristics, such as spring flow and water-table level [4-6]. As a result, karst aquifers are likely to respond to climate change. An increase in the magnitude of high-intensity precipitation events is already documented in the Black Hills region. Increased drought frequency and duration is exposing marginal lands to desertification [7].

\section{Geographic and Geologic Setting}

The Black Hills in western South Dakota and eastern Wyoming rise above the surrounding Great Plains, forming a startling contrast to the surrounding topography. Its eastern side rises from the prairie (650-900 $\mathrm{m}$ height level) to a height from up to $2100 \mathrm{~min}$ the western part of the Black Hills. 
The 290-km-long Black Hills uplift extends from the South Dakota-Nebraska border to southeast Montana. The general shape of the Black Hills is elliptical with a NNW-SSE-oriented axis.

Mainly three classes of rocks occur in this area: metamorphic, sedimentary, and igneous. The metamorphic rocks, schists, conglomerates, quartzites and limestones, are exposed in the central part of the region. The sedimentary series, extending from Cambrian to Quaternary, consist of limestones, sandstones, and shales. The Black Hills uplift affected of two north-trending structural blocks, the mutual boundary of which marks a zone of recurrent movement, at least in the Phanerozoic. A Proterozoic core is exposed in the eastern block. A 20 Ma episode of alkalic magmatism associated with the Laramide orogenic event which started in the Late Cretaceous, 70 to 80 million years ago, and ended 35 to 55 million years ago, formed dikes, sills, stocks, laccolithic domes, diatremes and ring complexes. Composite intrusions formed laccolithic clusters doming the basement. These occur in a westerly trending band which crosses the uplift, possibly along a deep basement fault which offsets the boundary of the Archean and Proterozoic provinces [8].

The Black Hills are surrounded by karst landscapes [9]. Relatively soluble rocks, including dolomite, limestone, gypsum and anhydrite, comprise about 35 percent of the total stratigraphic section within the topographic Black Hills [10-12]. Caves, sinking streams, and other karst features are found in limestones, gypsum, dolomites and anhydrite in several stratigraphic units in the Black Hills, South Dakota and Wyoming (Figure 1) The Limestone Plateau is located on the western side of the Black Hills along the South Dakota and Wyoming border, where large outcrops of the Madison Limestone and Minnelusa Formation occur in a high-altitude area of generally low relief [6]. The Black Hills are encircled by the lower elevations of the Red Valley, which is underlain by red clastic rocks of the Triassic-age Spearfish Formation and Jurassic-age Sundance Formation and other units. The foothills of the Black Hills are underlain by the steeply dipping Cretaceous-age Lakota Formation.

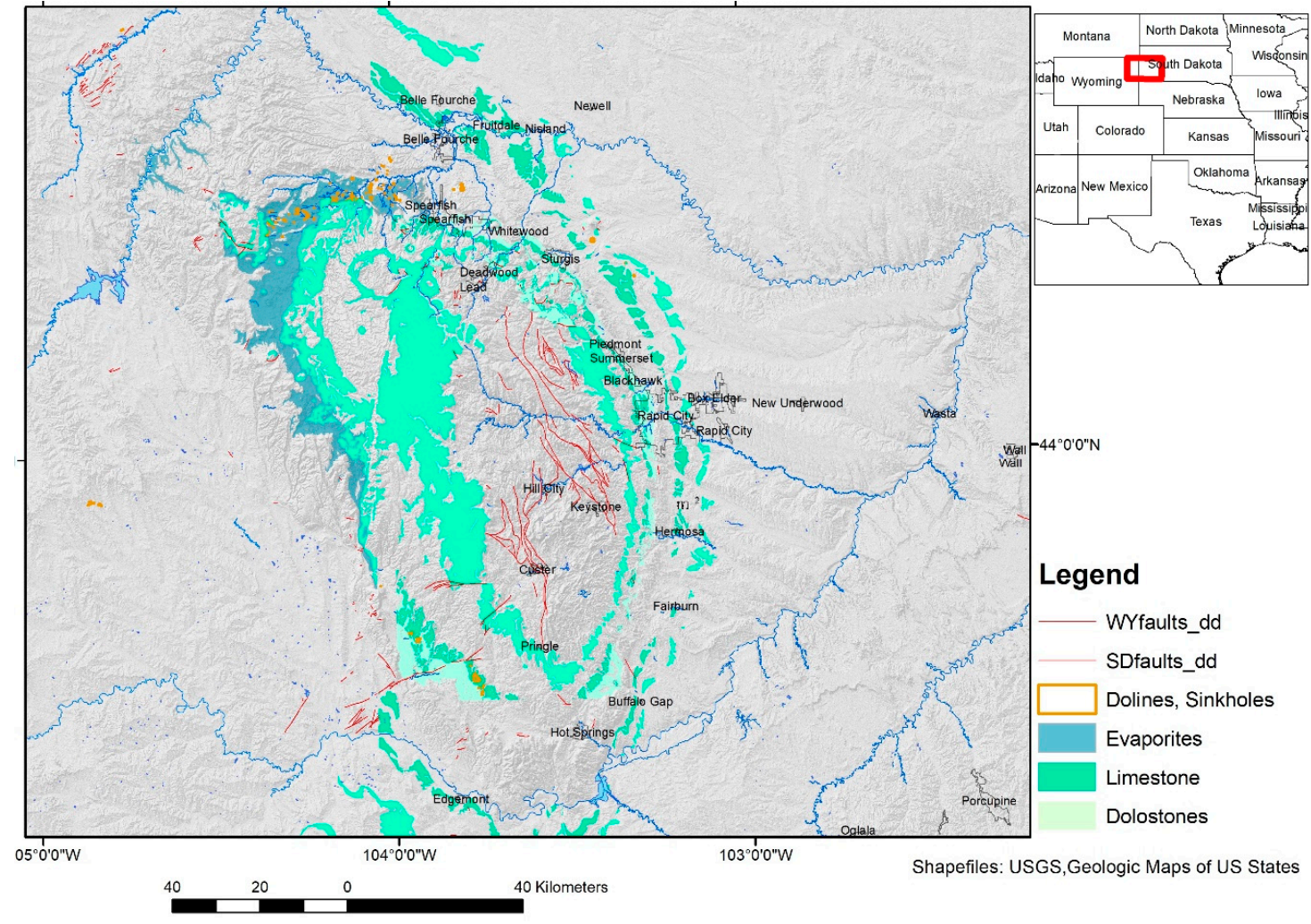

Figure 1. Lithologic units affected by karst processes in the Black Hills (source of the geologic shapefiles: US Geological Survey, South Dakota and Wyoming). The position of the area in the USA is indicated red in the overview map. 
The oldest karst features occur in the Mississippian Madison Limestone, a limestone-dolomite system that exhibits a karsted surface as well as extensive cave formation. The Pennsylvanian-Permian Minnelusa Formation contains anhydrite and thin limestone beds that have undergone localized and varied karstification. Hydration and swelling of primary anhydrite has resulted in multiple collapse structures within the formation. The Triassic Spearfish Formation contains gypsum deposits throughout; however, massively bedded gypsum up to $10 \mathrm{~m}$ thick is contained at the top in the Gypsum Spring Member. Evaporite karst has developed extensively in the anhydrite and gypsum in the Minnelusa, Spearfish, and Gypsum Spring Formations [10-12].

There are solution dolines considered to be formed by a gradual process of sagging or settling of the overlying deposits into the depression. Solution dolines are usually characterized by gentle slopes with no obvious rupturing of the soil or surface. Bedrock collapse dolines are caused by collapse of bedrock into an underlying void.

The question arises how climate change will affect the karstification processes in this area. These dissolution processes depend on surface water input that will be affected by climate conditions. The Black Hills region has a continental climate characterized by low precipitation, hot summers, cold winters, and extreme variability [6]. The largest precipitation amounts typically occur during May and June, and the smallest amounts typically occur during November through February [5]. Orography affects climate with colder temperatures and higher precipitation at higher altitudes. The northern Black Hills is affected by moist air from the northwest, and the southern Black Hills is affected by drier air from the south-southeast. Storm events with heavy rain causing flash floods, less snow cover and more humid winters will have an impact on karstification intensity and, thus, on sinkhole, solution fissures and on cave development.

Climate change might affect the following factors influencing karstification:

- Vegetation condition and cover

- Morphometric properties of dolines and depressions due to changing morphodynamic conditions (slope degree, depth, etc.)

- Sediment input into sinkholes as response to heavy rainfall

- Solution processes

- Weathering processes, soil development, salinization of water bodies

Another question arises related to ongoing tectonic processes in the Black Hills. Earthquakes and neotectonic movements (uplift, subsidence) will have an influence on fault and fracture zones in lithologic units prone to karst processes as geomechanical dynamics play an important role in karstification development. Conduits in karst groundwater are formed from rock dissolution along planes or discontinuities where the flow has characteristics similar to the water surface. Endokarst environments are typically characterized by open conduits with low capacity for storage and rapid groundwater flow [9].

A sinkholes inventory map is one of the main steps towards sinkhole susceptibility analysis, hazard evaluation, and risk management (Figure 2). A systematic mapping and typification of karst features in and around the Black Hills is not published so far. Detailed doline maps are missing. Thus, the purpose of this study is:

(1) to develop a standardized karst feature database,

(2) to investigate critical indicators associated with doline occurrence and collapse, and,

(3) lineament analysis in affected areas for the detection of the influence of subsurface structures (faults and fracture zones) on karstification processes and their distribution. 


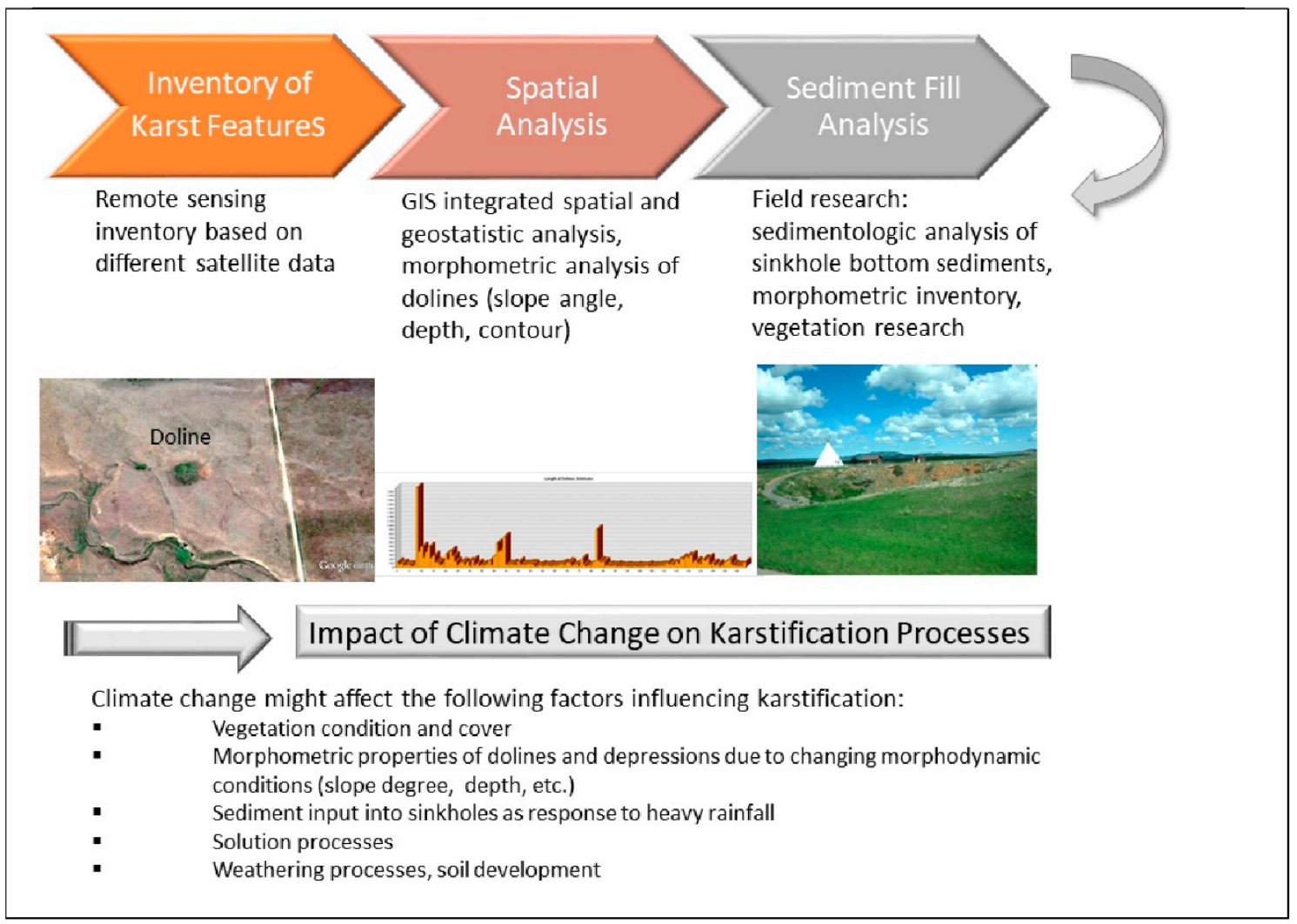

Figure 2. Workflow for the detection and inventory of karst features.

\section{Data and Methods}

GIS integrated remote sensing data and geospatial geodata analysis was used for the inventory of karst features and to visualize factors influencing the intensity of karstification.

\subsection{Evaluations of Different Satellite Data}

Landsat and Aster data provided free by the USGS (United States Geological Survey) [13], EarthExplorer, the Global Land Cover Facility (GLCF), University of Maryland, USA and Sentinel 2-images from European Space Agency (ESA) were used for evaluations. RapidEye and PlanetScope images were included into these investigations (supported by the Planet Team: Planet Application Program Interface: In Space for Life on Earth. San Francisco, CA, USA). The satellite data were digitally processed using image processing (ENVI, Sentinel Application Platform-SNAP) and ArcGIS software (ESRI Company, Redlands, CA, USA). Based on the different satellite data false color composites (Red, Green, Blue-RGB combinations) of the different bands were used. The chosen image processing and RGB-combinations were focused on the enhancement of geologic, tectonic information. Low pass and high pass filters and directional variations supported the detection of subtle surface structures such as linear escarpments and sinkholes. Merging the "morphologic" image products derived from "Filter-Convolutions and Morphology—Directional" image processing in ENVI software with RGB imageries, the evaluation feasibilities were improved. Principal Component analysis (PC) of the RGB images revealed structural and lithologic information as well.

Special attention was directed at precise mapping of traces of the tectonic pattern visible on satellite imageries, predominantly on areas with distinct expressed linear features (tonal linear anomalies, geomorphologic linear features, etc.) as lineament analysis supports the detection of faults and fracture zones influencing the development of karst features. The term lineament is a neutral term for all linear, rectilinear or slightly bended image elements. Lineaments are often expressed as scarps, linear 
valleys, narrow depressions, linear zones of abundant watering, drainage network, peculiar vegetation, landscape and geologic anomalies. Linear arrangement of pixels depicting the same color/gray tone were mapped as lineaments. Lineaments represent in many cases the surface expression of faults, fractures or lithologic discontinuities. Especially, when it is difficult to identify faults and lineaments in the field, because of geological conditions like sedimentary covers, erosion, over-growth of vegetation, scale, and other factors, remote sensing is a valuable additional tool. In the scope of this study mainly 3 types of linear and curvi-linear features were mapped: lineaments, probable fault zones, and structural features. As traces of structural features were considered deformations due to stress such as synclines or anticlines, bedding structures, foliation that become visible as dense, arc-shaped, parallel lines. The mapped lineaments were compared then with available fault data from the USGS.

The visibility of linear and curvi-linear features depends on the specific properties of the satellite systems such as their spatial and radiometric resolution or acquisition time. Thus, the structural analysis was carried out in the scope of this research based on optical satellite imageries and Sentinel and Advanced Land Observing Satellite (ALOS)-Phased Array type L-band Synthetic Aperture Radar (PALSAR) radar data, as well as on high spatial resolution Bing Map Aerial of Microsoft, Google Earth and World-Imagery layers and ArcGIS Earth provided by ESRI.

For the detection of seasonal influences on the landscape and of the potential impact of climate change satellite images from all seasons were evaluated over the last decades. RapidEye images available since 2009 and Planet scope images provided the necessary data base.

\subsection{GIS Integrated Morphometric Analysis of DEM Data}

Morphometric maps derived from digital elevation data such as the Shuttle Radar Topography Mission (SRTM), Advanced Spaceborne Thermal Emission and Reflection Radiometer (ASTER) global digital elevation model (GDEM) data and Advanced Land Observing Satellite (ALOS)-Phased Array type L-band Synthetic Aperture Radar (PALSAR) DEM data supported the lineament analysis by visualizing linear, morphologic features. ALOS-PALSAR-DEM data with $12.5 \mathrm{~m}$ spatial resolution from the Alaska Satellite Facility, USA were included into these investigations as well. The combined evaluation of these different satellite data allowed a more detailed inventory of the structural pattern as far as possible by the use of remote sensing tools. Thus, the evaluations contribute to the detection of the structural influence on karst processes. These data and tools were used especially for the mapping of circular/elliptic features that might be related to karst features such as dolines and depressions. The morphometric analysis of Digital Elevation Model (DEM) data helped to visualize the small-scaled variations at the surface. From DEM-data derived morphometric maps (slope gradient maps, height level, drainage, etc.) were used for the detection of karst phenomena. However, the majority of the dolines are less than $100 \mathrm{~m}$, even less than $20 \mathrm{~m}$ in size. Dolines are often smaller than the $30 \mathrm{~m}$ spatial resolution of SRTM DEM and ASTER GDEM data and, thus, not visible on the DEM data derived morphometric maps.

Several useful tools for processing digital elevation data exist in ArcGIS, especially the hydrology tools and the surface tools that have been successfully used in other karst prone areas [14,15]. The detection and inventory of dolines was carried out by combining the extraction of sink depth from DEMs, morphometric analysis using GIS, and visual interpretation). Aiming to detect circular or oval shaped depressions a digital map of depressions can be obtained by the map algebra operation of subtracting the depression-free DEM from the original DEM: (Fill-Aster-Mosaic)_(Aster-Mosaic) or the Sink-Tool in ArcGIS. The methodology is a semi-automatic approach involving several steps: (a) DEM acquisition and (b) sink-depth calculation using the difference between the raw DEM and the corresponding DEM with sinks filled. The first step used the "Fillsink" algorithm from the ArcMap software package that identifies the point or set of adjacent points surrounded by neighbors with higher elevation and rises to the lowest value on the depressions boundary. This procedure then fills all depressions in the DEM, including both those generated from data errors (spurious artifacts) and those that record real topographic features, such as karst depressions. The second step was to extract the sink 
depths in these areas by differencing the maps between the sink-filled ("depressionless" DEM) and original DEM [15]. The difference image should highlight the different depressions, including the karst enclosed depressions. However, due to the size of most of the closed depressions in the Black Hills it is difficult or not possible to identify the smaller depressions based on these data. Thus, the visual evaluation became the more reliable part of these investigations. Another difficulty are numerous man-made reservoirs and quarries within and in the adjacent areas of the Black Hills appearing as sinks or depressions on the DEM derived maps. To avoid errors a visual evaluation of the remote sensing data and field research has to be combined with the sink extraction.

When searching for areas relatively more susceptible to karst processes than the environment due to higher surface water input, the so called causal factors have to be taken into account that might be of influence. As the lowest and flattest areas are prone to higher amounts of surface water input after precipitations than the higher, surrounding environment, the weighted overlay and weighted sum of morphometric factors in ArcGIS (lowest local height level, lowest dropraster values, slope degree $<10^{\circ}$, curvature $=0$ ) help to identify those regions [16].

\section{Results}

Based on the evaluation of the different satellite data several types of circular features related to karst phenomena could be detected:

- Larger circular features with several hundred meters up to $2 \mathrm{~km}$ diameter (origin has still to be investigated and verified), see Figure $3 \mathrm{~A}$

- Enclosed, circular depression caused by solution and erosion processes, up to $300 \mathrm{~m}$ in diameter (Figure 3B)

- $\quad$ Bedrock collapse dolines, $10-100 \mathrm{~m}$ in diameter (Figure 3C)

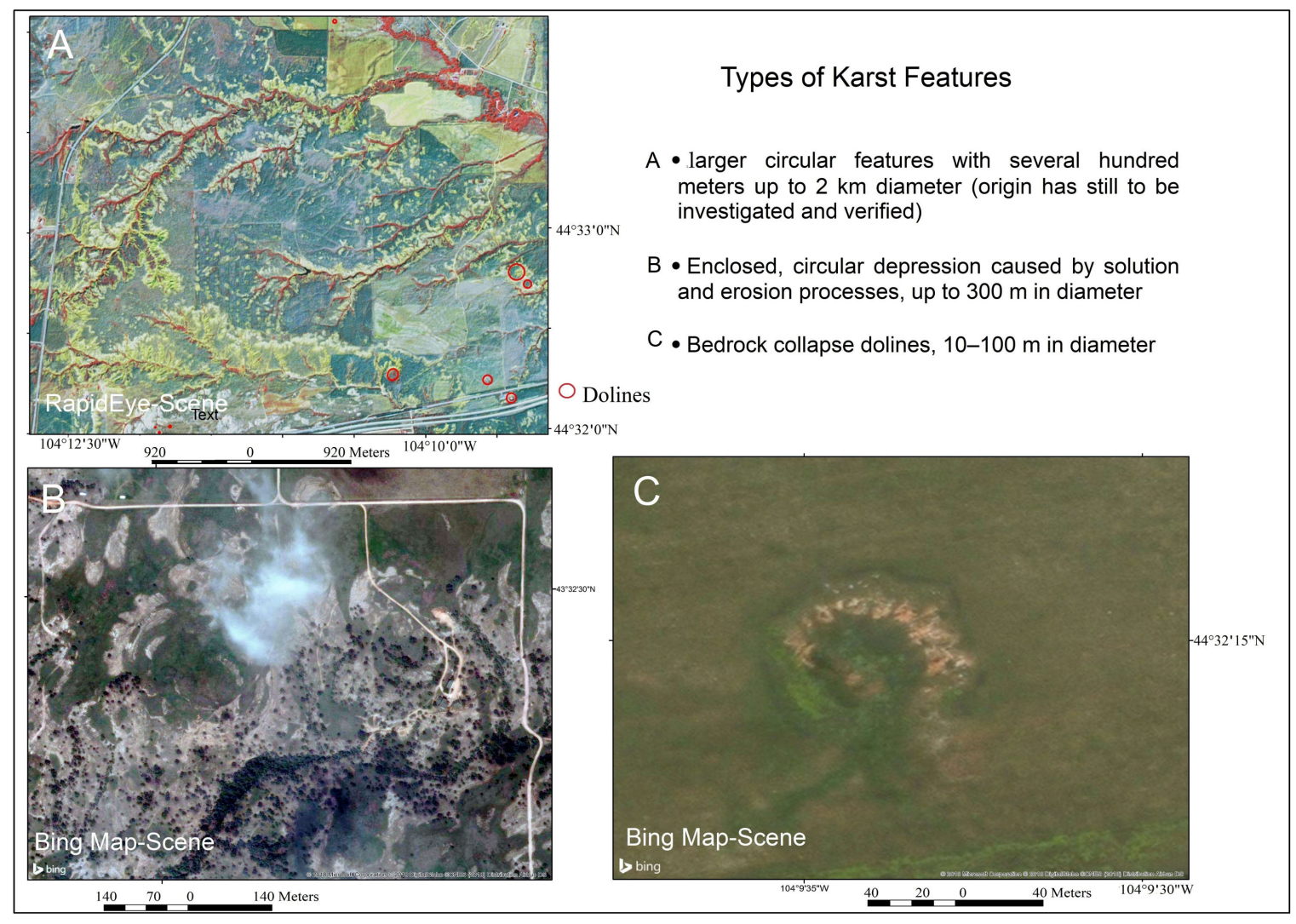

Figure 3. Different forms and types of sinkholes and depressions with complex origin. 
Morphometric parameters such as circularity, the geographic orientation of the main doline axes, and the length-to-width doline ratios support the categorization of karst features. However, depressions and dolines may be categorized and characterized by their morphology and morphometry, but their genetic origin cannot be deduced from their dimensions or shape. Field work has to be carried out to verify the origin.

Figure $4 \mathrm{a}, \mathrm{b}$ show the length and area distribution of the so far mapped sinkholes and depressions as indicated on the map. When analyzing the length of the mapped sinkholes and depressions it becomes obvious that collapsed dolines are the smallest karst features visible on satellite images with less than $10-40 \mathrm{~m}$ in diameter.
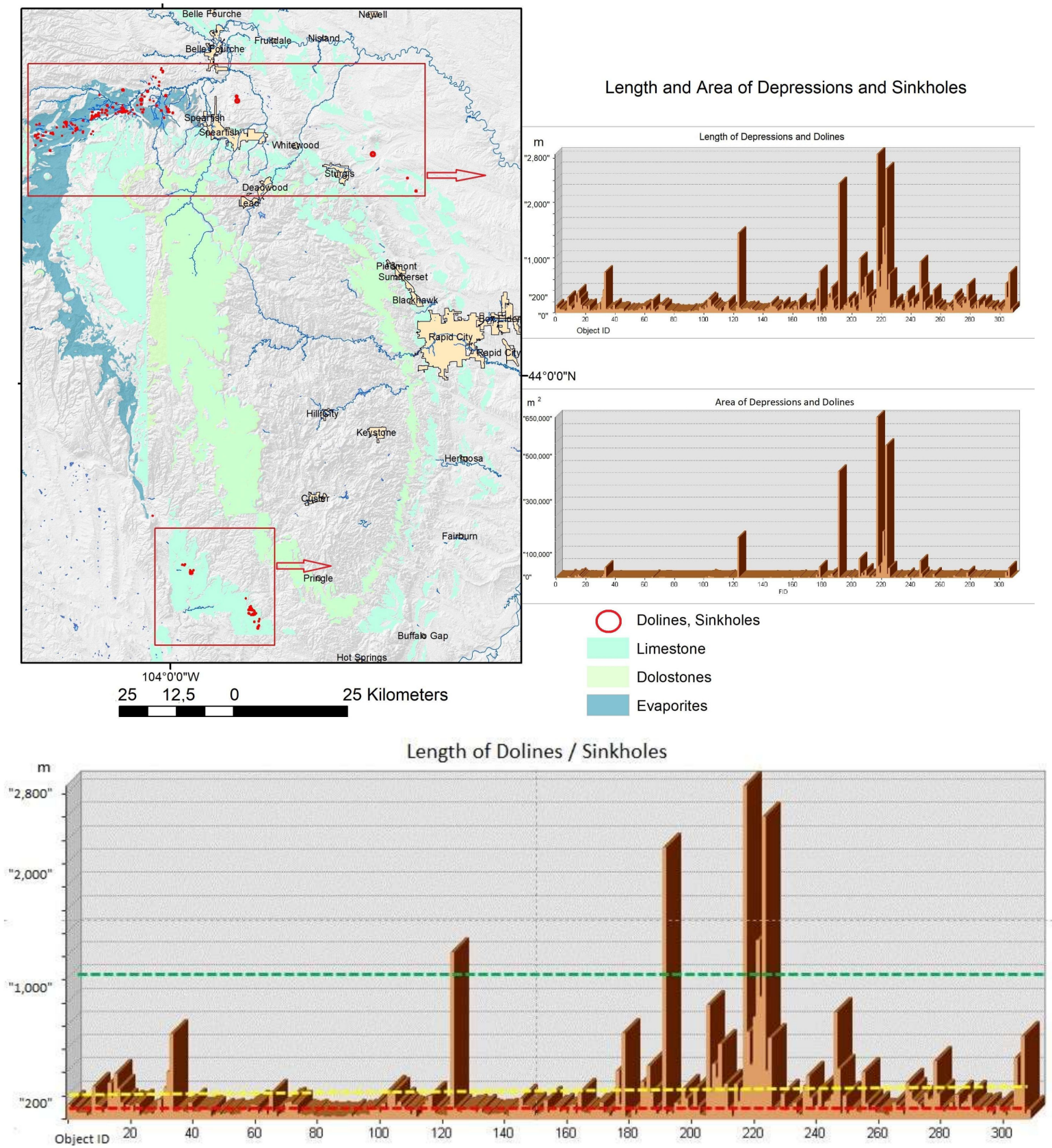

Figure 4. (a) Length and area size of depressions and sinkholes from the test sites; (b) Size of depressions and sinkholes according to their assumed origin.3.1. Circular Features. 
In the Northern Black Hills several larger circular features could be detected on the satellite images, mainly based on the concentric drainage pattern and erosional features (Figure 5). When including vegetation index and water index-images in the evaluations, the circular outline becomes even more evident. Whether their origin can be correlated with karst solution processes in the subsurface or to igneous intrusions updoming the layers above has still to be investigated. Sentinel-1 radar (C-Band Synthetic Aperture Radar, vertical polarization) data of this area reveal this circular structure as well. Another circular feature is visible northeast of Beulah, WY, due to the concentric arrangement of limestones forming al ring around a central depression and the concentric drainage pattern (Figure 6).

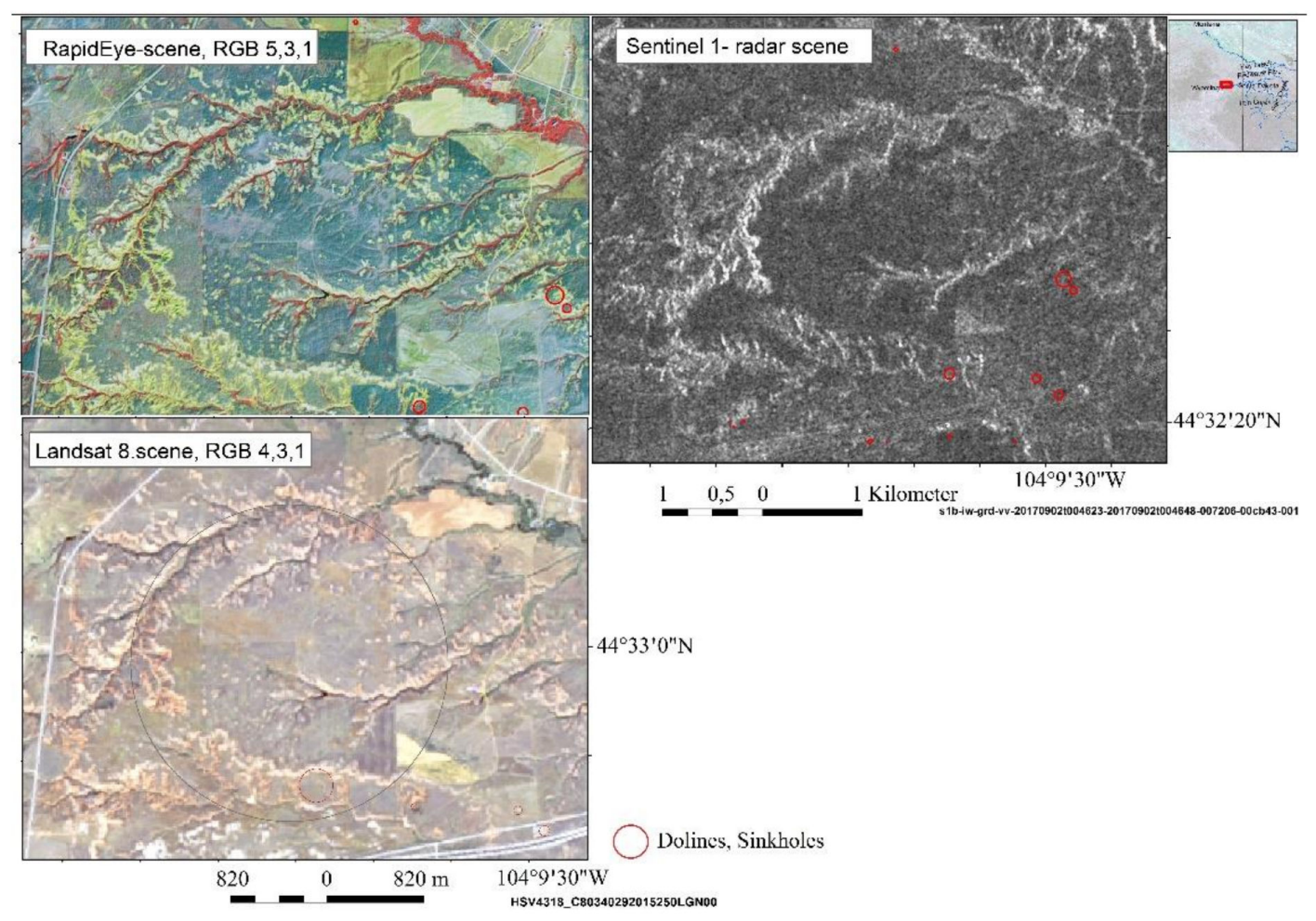

Figure 5. Large, circular feature as visible on RapidEye, Landsat and Sentinel-1-images due to the concentric drainage pattern with smaller dolines (red circles) at the border.

\subsection{Enclosed Circular Depressions}

Most of the sinkholes and depressions in the investigation area are assumed to be caused by solution processes, forming enclosed depressions that can be regarded as the most common landforms of karst in the Black Hills and its surrounding area. They are developed as surface features due to locally more intense solution. They are obviously funneling rainfall and runoff downwards. They range in diameter from a few meters to several hundred meters. Their shapes, particularly the outline of their cross sections, depend to a great deal on local lithological and soil conditions and the structural pattern. Lineament analysis contributes to the detection of this structural influence. Examples of enclosed depressions are shown in Figures 7-9.

It can be observed, that the development of karst features has been more intense in the northwestern and western part of the Black Hills in comparison with the eastern part of the karst prone rock units. This can be explained by the structural and lithologic setting, but one further reason for this might be orographic effects, the exposition to the luv and lee effects of rain bearing winds. Several multi-ringed, complex depression can be observed on the satellite images such as in Figures 8 and 9, probably resulting from subsurface dissolution and/or downward gravitational movement of cover deposits and/or from selective erosion. 


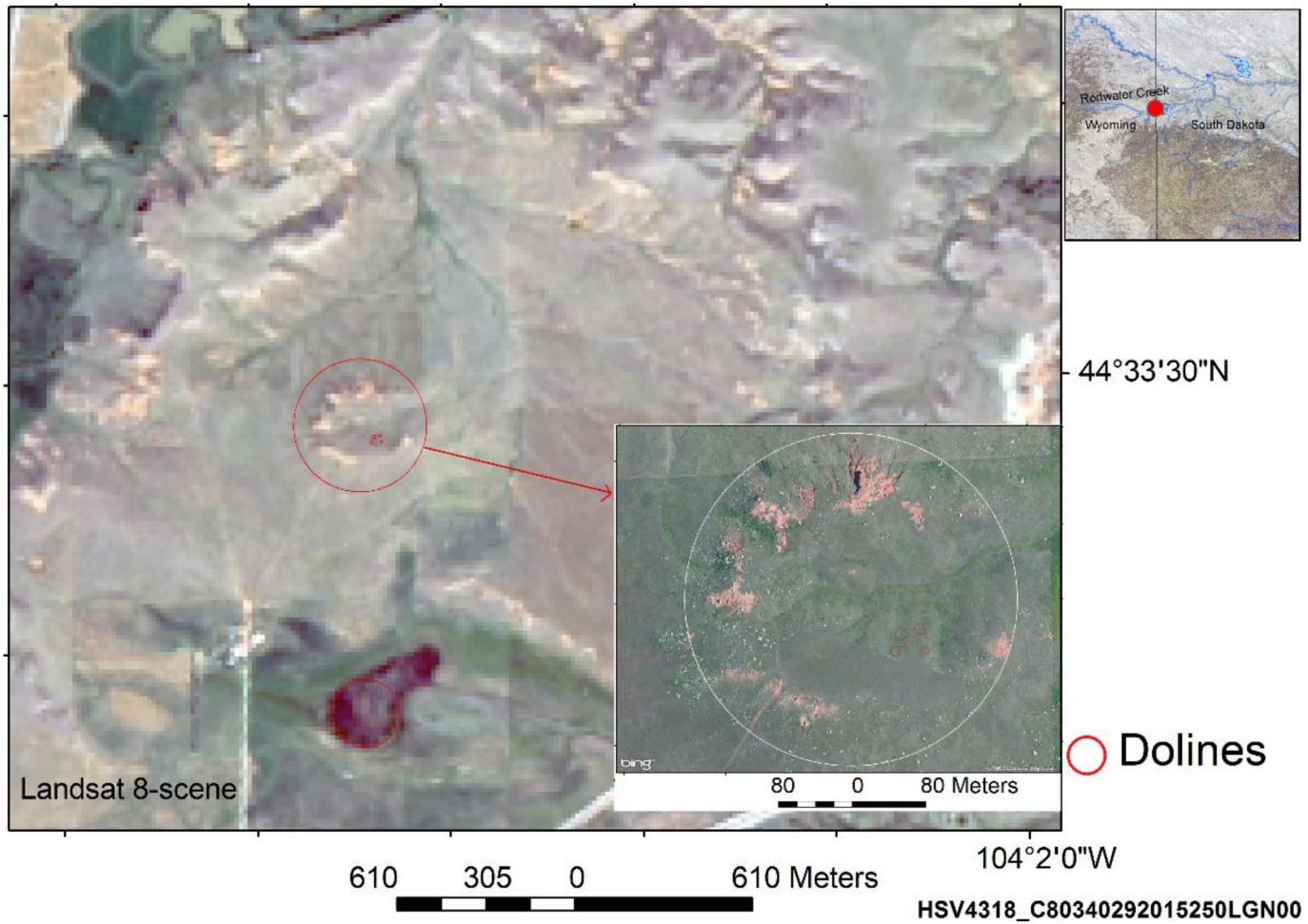

Figure 6. Circular feature northeast of Beulah, Wyoming (WY), visible on satellite imageries (Landsat 8 and Bing Map) with partly unknown origin (karst, igneous intrusions updoming strata above?).

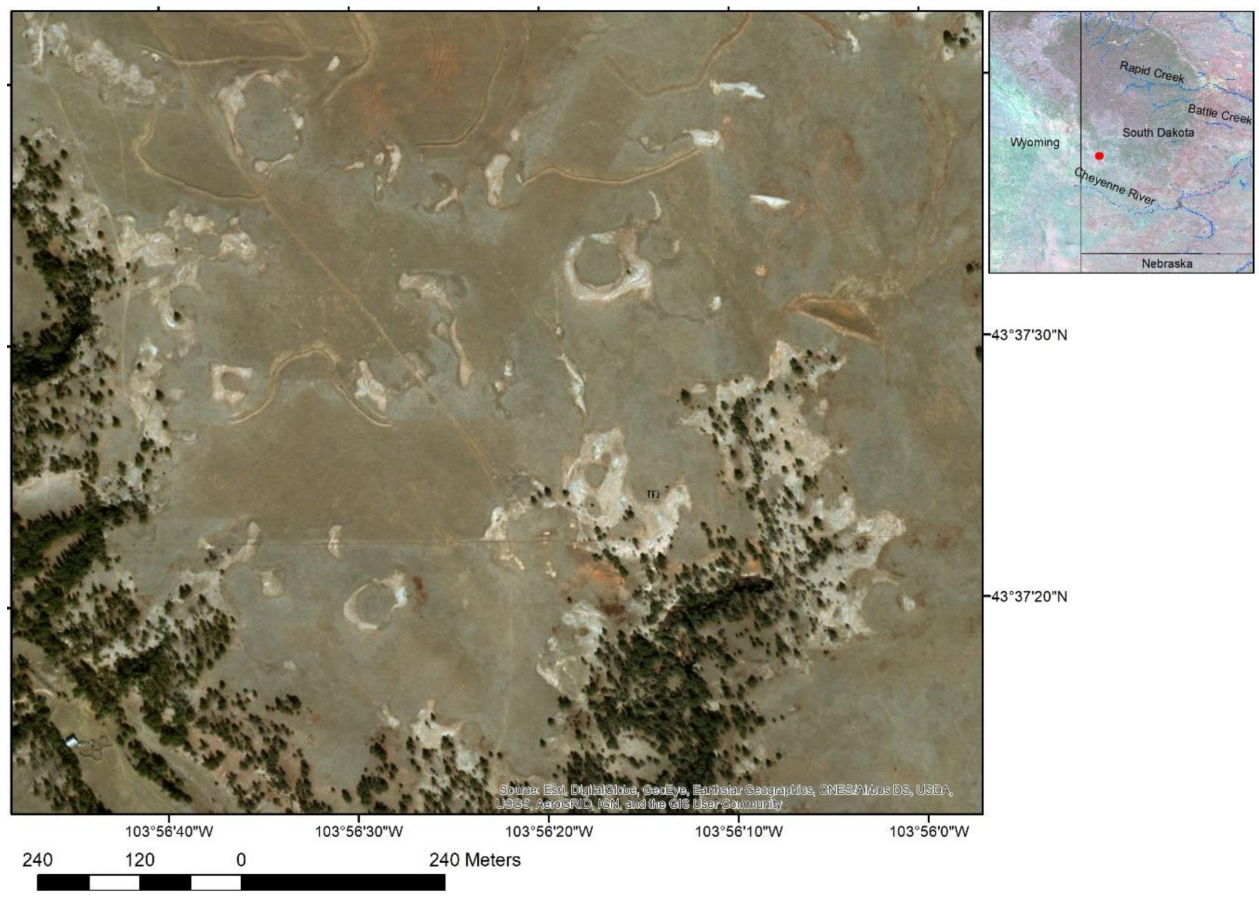

Figure 7. Enclosed Depressions in the Minnekahta-limestone area in the SW of the Black Hills. 

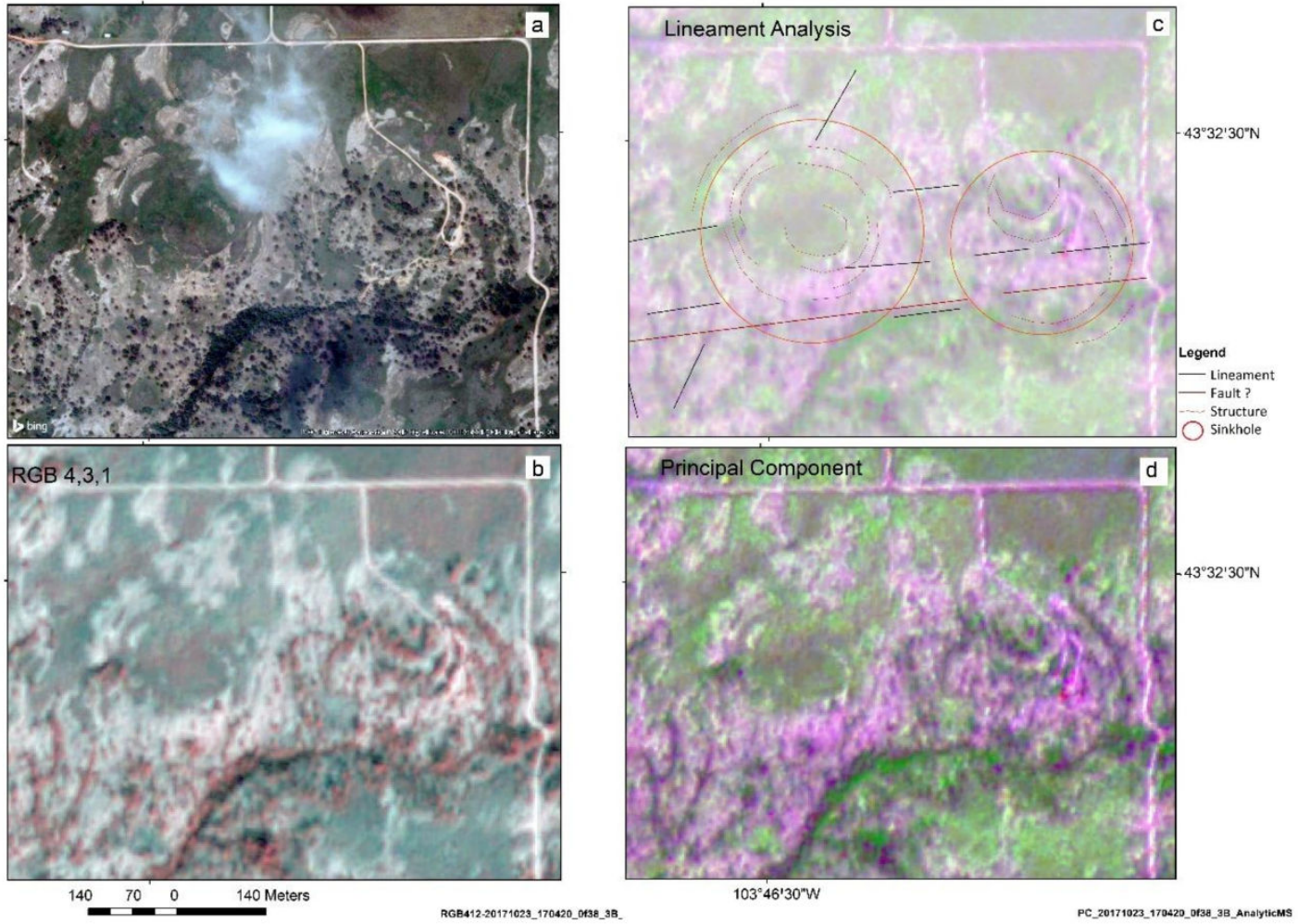

Figure 8. Multi-ringed, circular structures due to dissolution, selective erosion and subsidence processes in the southwest of the Black Hills visible on a Bing Map-image (a) and PlanetScope scenes (b-d) and including lineament analysis (c).

Topographic cross sections based on ALOS-PALSAR DEM data show that these complex circular features are shallow, partly have poorly defined edges and reach up to several hundred meters in diameter (Figure 9). Thorough field surveys have still to be carried out to check depressions of a complex origin detected by remote sensing techniques.

\subsection{Collapse-Dolines}

The collapsed dolines occur mainly in the evaporitic rock units. The visible collapse dolines, caused generally by collapse of bedrock into underlying voids, are generally smaller than $50 \mathrm{~m}$ in diameter in the Black Hills area. Although solution is a significant process driving the creation of these dolines, they seem to be more due to mechanical processes. The following figure show examples of collapse dolines near the Interstate 90, where the "Vore Buffalo Jump" forms an $18 \mathrm{~m}$ deep sinkhole [11], Figure 10, (2). Further karst features are located northwest of the Vore Buffalo Jump on Figure 10. A gypsum bed lies immediately above the Minnekahta Limestone and also underlies the sinkholes. Another gypsum bed outcrops above and to the north of the sinkholes [12,13]. The surface alignments of karst features often are associated with joint patterns, faulting and folding. Fractures significantly influenced the location, pattern and detailed shape of sinkholes. Linear arranged dolines/uvalas are visible in Figure 11, following a WNW-ESE oriented fracture zone. Lineament analysis might support the detection of faults and fracture zones influencing the development of karst features and the development of the drainage pattern. Sinkholes occur often within and in the surrounding of drainage lines (Figure 12). Doline fields within basins and larger riverbeds are a common feature in the northwestern part of the Black Hills. When investigating the geomorphologic and geologic setting of the doline fields surrounding the Black Hills the geomorphologic analysis shows similarities. The doline fields are situated within larger valleys and basins, however, most of the dolines are not concentrated in the lowest valley parts, but more near the foot slopes, where surface water run-off 
from the upper hills and infiltration into the down-slope sediments is providing the water for the dissolution processes.

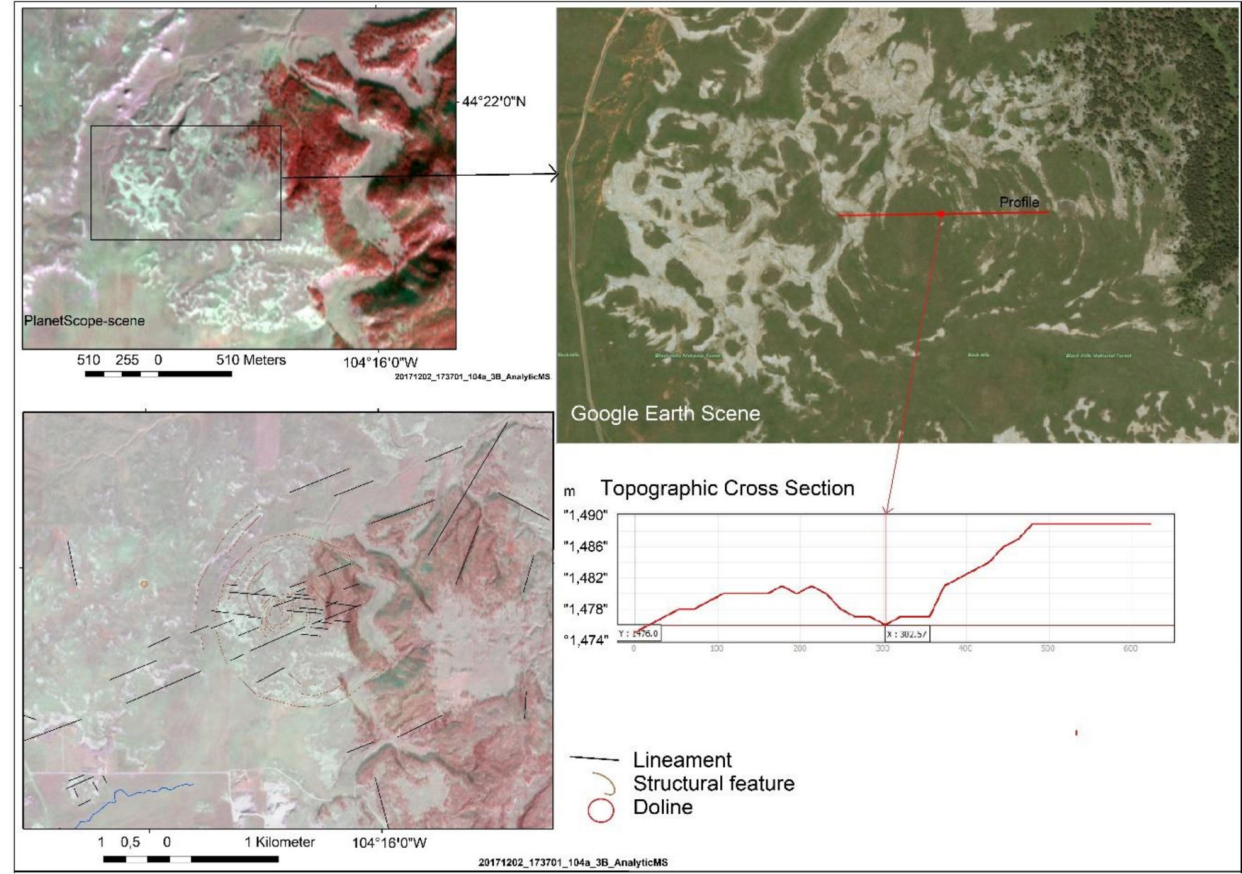

Figure 9. Circular, multi-ringed structures in the western part of the Black Hills.
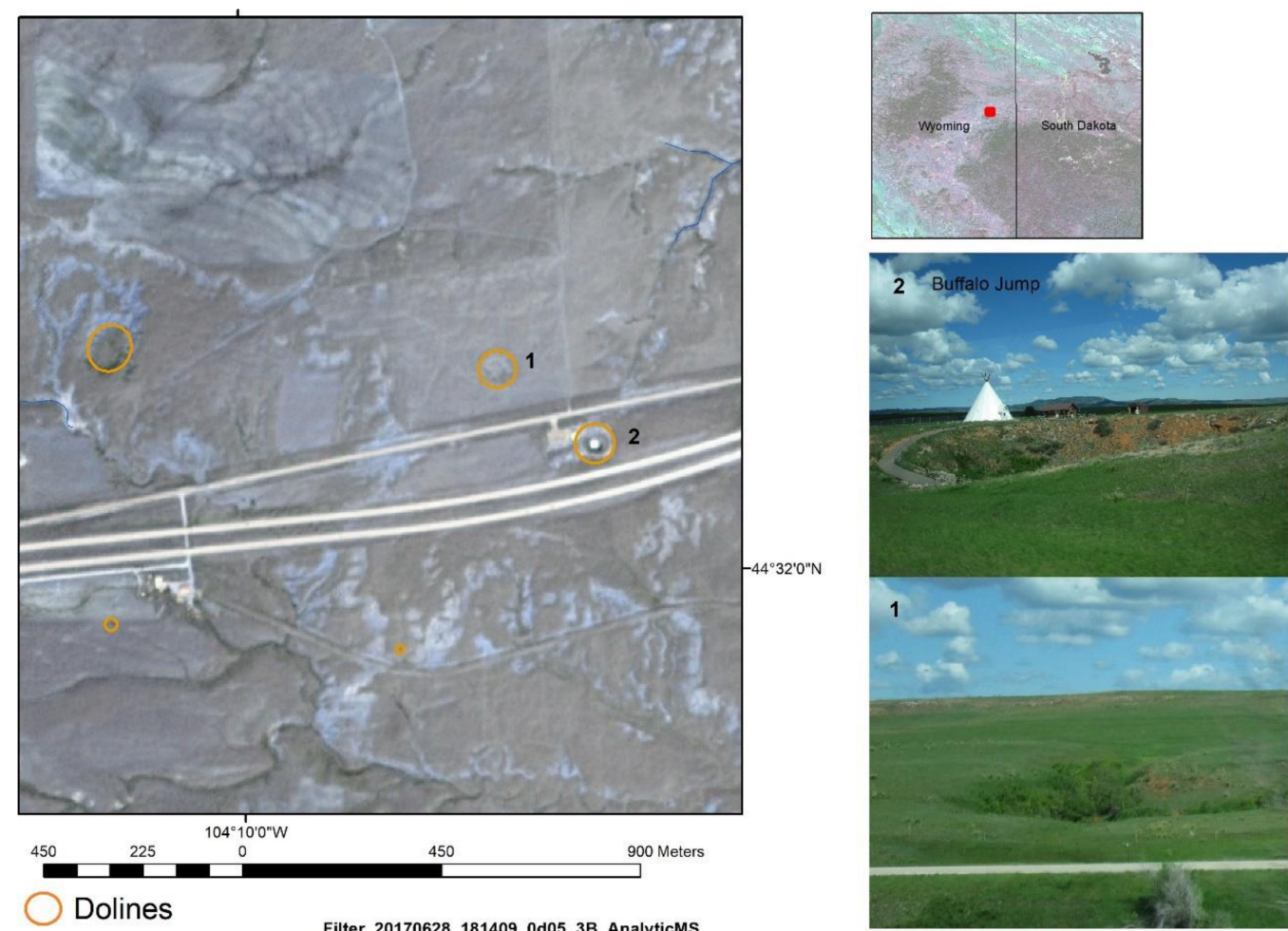

Figure 10. Buffalo Jump (2) collapsed doline visible on a PlanetScope scene and on field images (taken by Theilen-Willige, May 2017). 


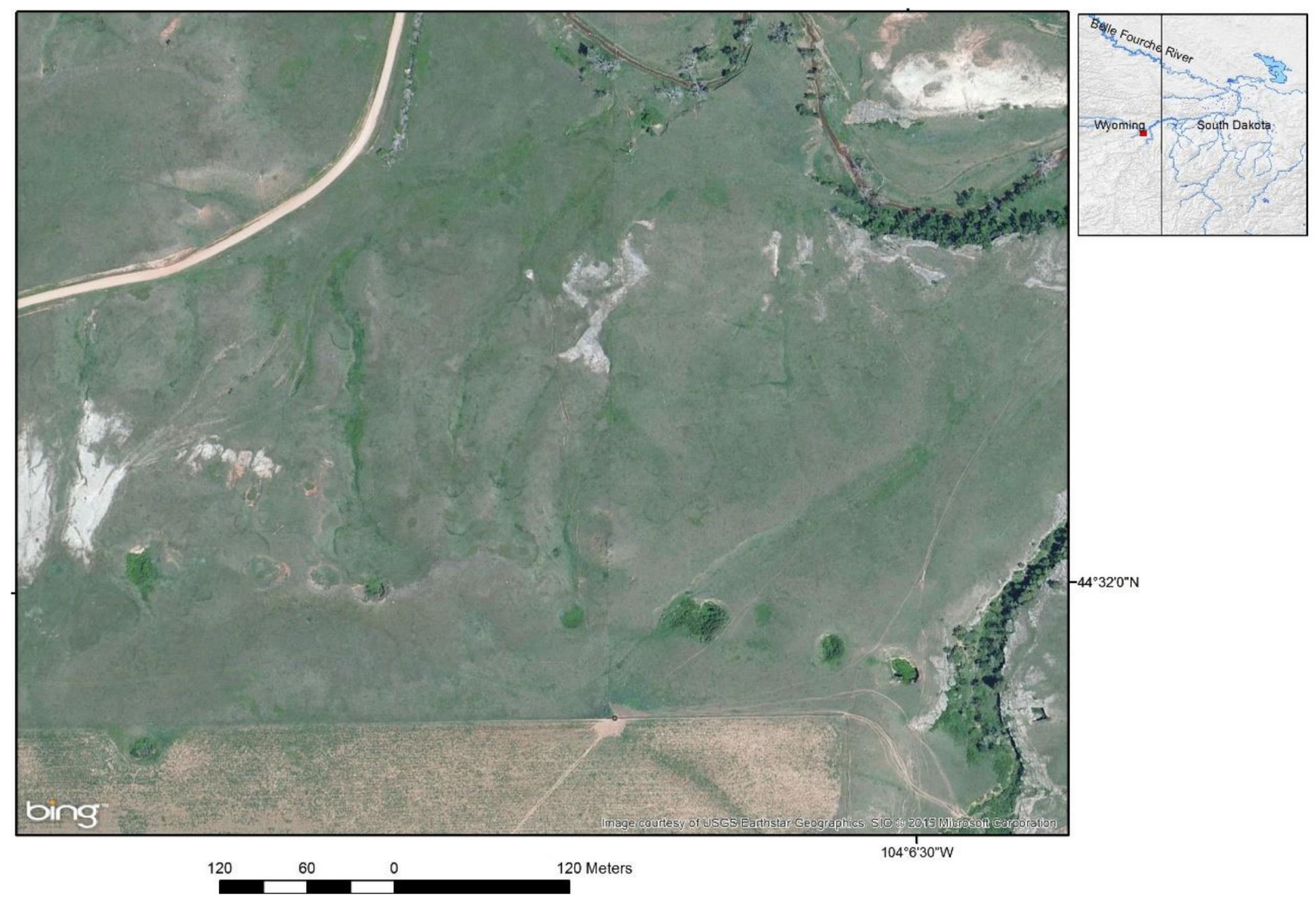

Figure 11. ENE-WSW striking fracture zones influencing the linear arrangement of dolines/uvalas.

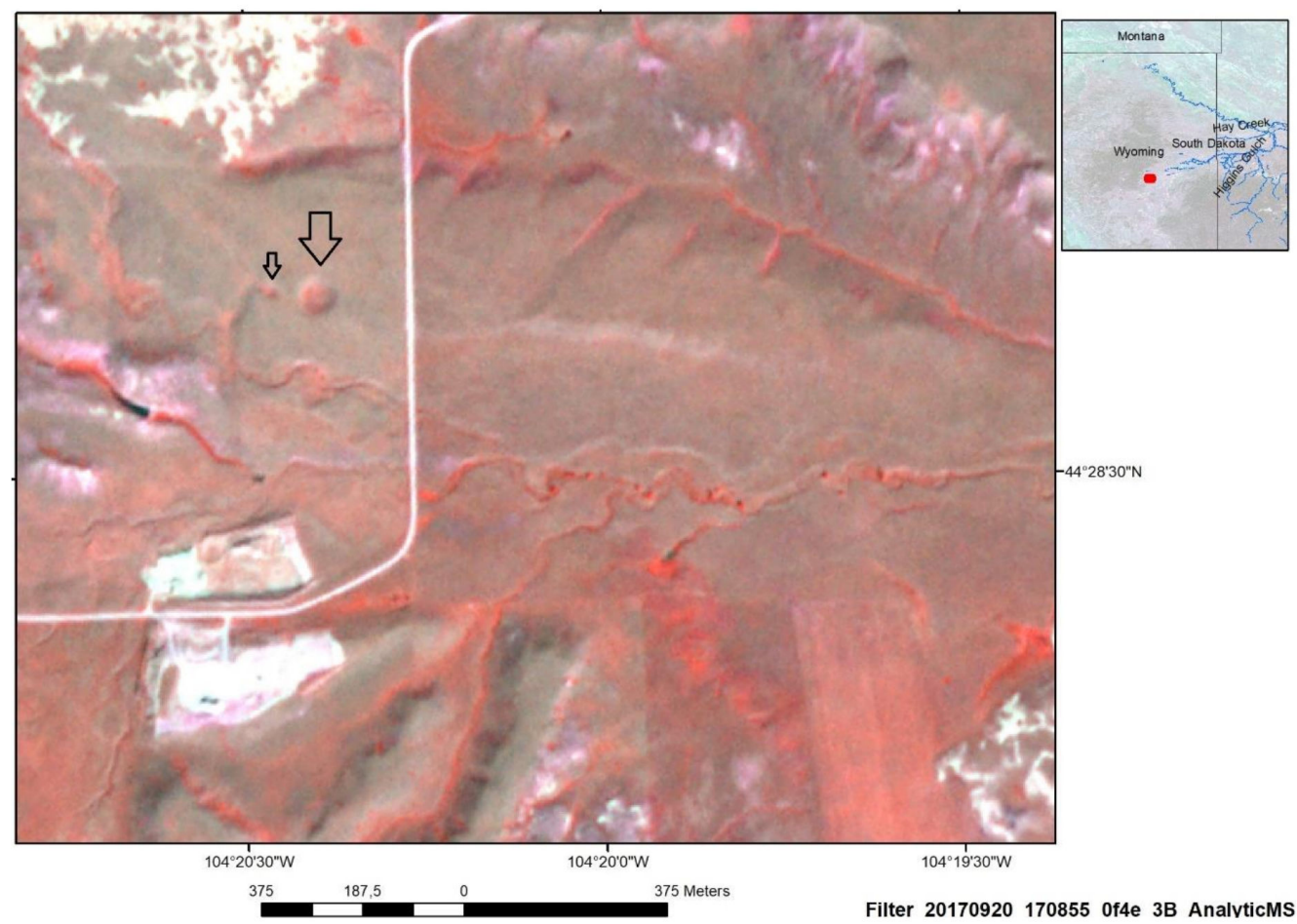

Figure 12. Dolines (indicated by the black arrows) and linear drainage pattern visible on a RGB (Bands 4,2,1)-PlanetScope-image. 
Doline fields are visible especially on images covered with thin layers of snow (Figure 13) in winter time or on images taken shortly after rain fall (Figure 14). During the humid season the small dolines, often with less than $20 \mathrm{~m}$ in diameter, are temporarily filled with water forming then circular ponds (Figure 14b and Figure 15). Further on, seasonal high ground water tables in the depressions surrounding of the Black Hills result as well from direct infiltration of rainfall and snow melt at high altitudes of the central Black Hills which flow outward and down-dip through the rimming sediments, accumulating then in depressions. During the dry season there is no water body visible.

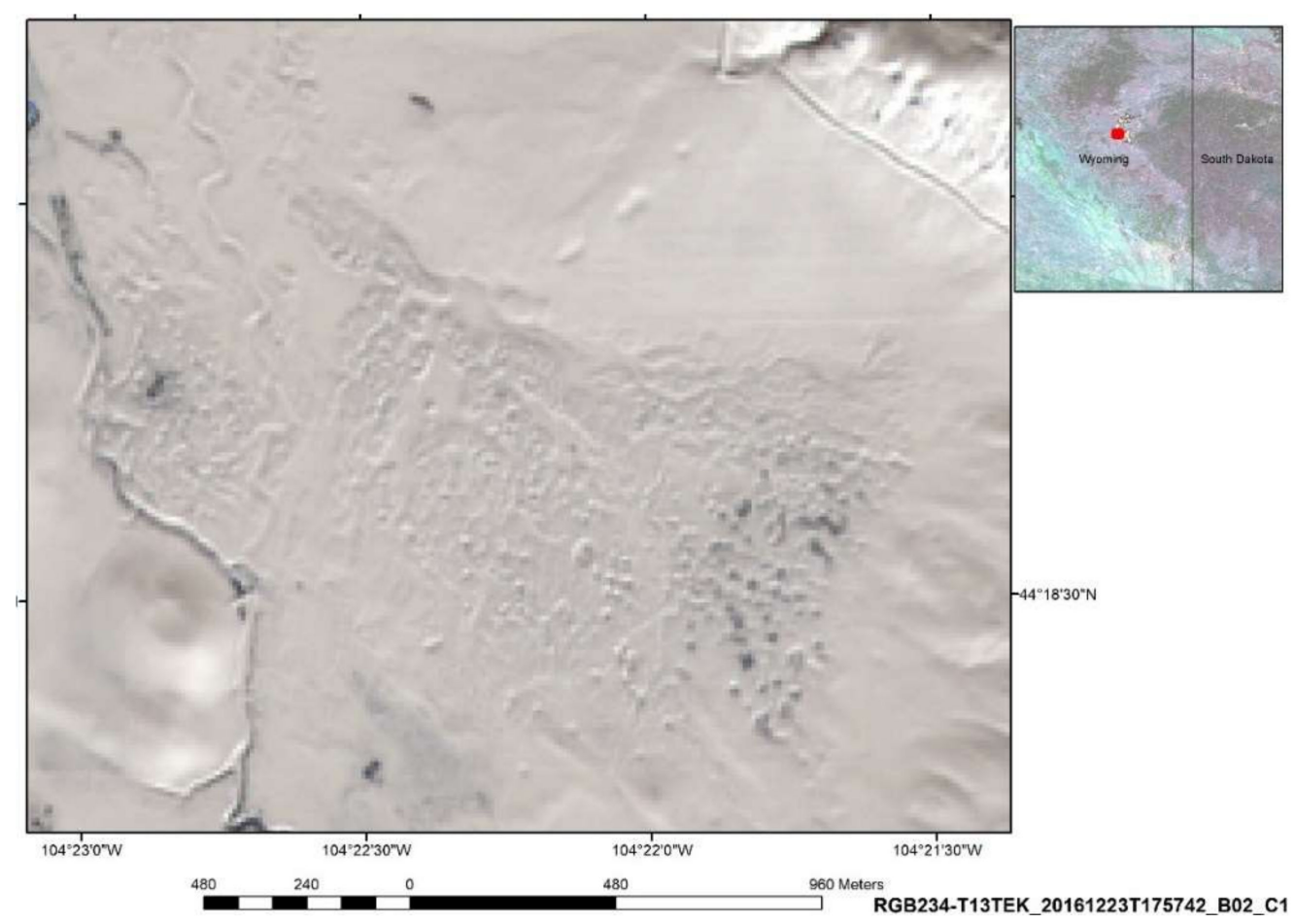

(a)

Figure 13. Cont. 

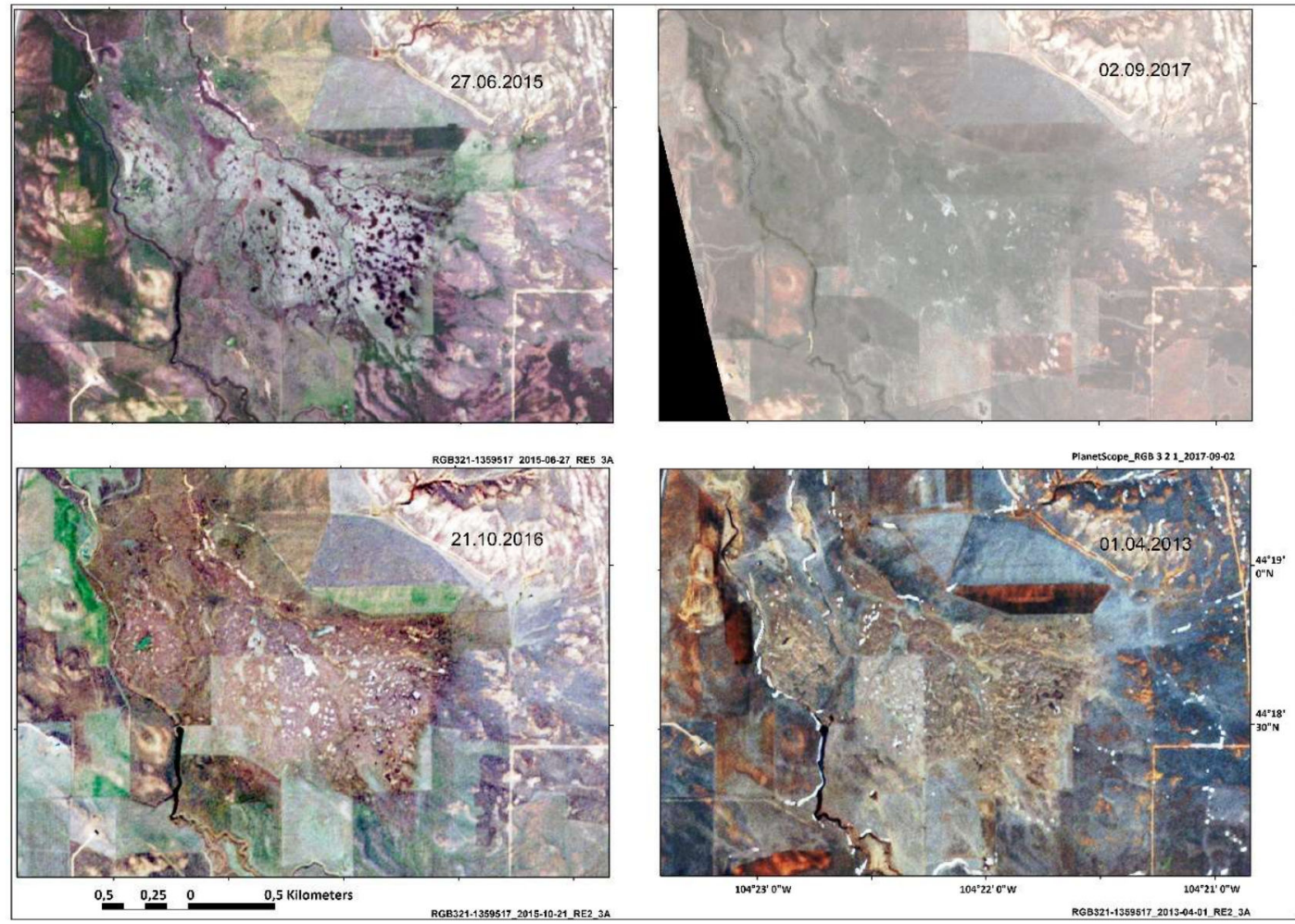

(b)

Figure 13. (a) Doline fields in evaporitic rocks in the NW of the Black Hills visible on a Sentinel 2-scene with snow cover (b) Seasonal impact visible on RapidEye- and PlanetScope-scenes (RGB: bands 3,2,1) of the doline field area showing water-filled dolines during the humid season (May-June), nearly invisible, dried dolines during the dry season and snow covered dolines in winter times.

The structural influence on doline development can be partly derived from lineament analysis. When evaluating the RapidEye-scenes the linear arrangement of the small ponds becomes obvious, leading to the conclusion that subsurface structures have an influence on their distribution (Figure 14). The doline clusters occur in areas where SW-NE and SE-NW oriented lineaments are intersecting.

Dolines and karst valleys are covered longer with denser vegetation revealing higher photo-synthetic vitality due to the relatively higher soil moisture in the depressions than the environment. Figure 15 shows a PlanetScope-scene of a doline field in the northwestern part of the Black Hills (dolines are visible in red colors). These figures are available as well in the Supplementary Material S1, that can be downloaded, see link to the Supplementary Material at the end of this article.

Trying to detect collapsed dolines based on DEM data-derived maps, such as the sink calculation, does not provide results related to dolines in the investigation area. The difference between the Fill-DEM and the original DEM shows the sinks, situated mostly within river beds on both, SRTM and ASTER DEM derived sink calculations. Although presenting a higher spatial resolution, the ALOS-PALSAR DEM derived maps show even less evidence and correlation with depressions and sinkholes related to karst. The ALOS-PALSAR-calculated sinks are situated within riverbeds and drainage courses as well (Figure 16a,b). Thus, the sink calculation seems not to be suited for the detection and inventory of sinkholes in this area. 


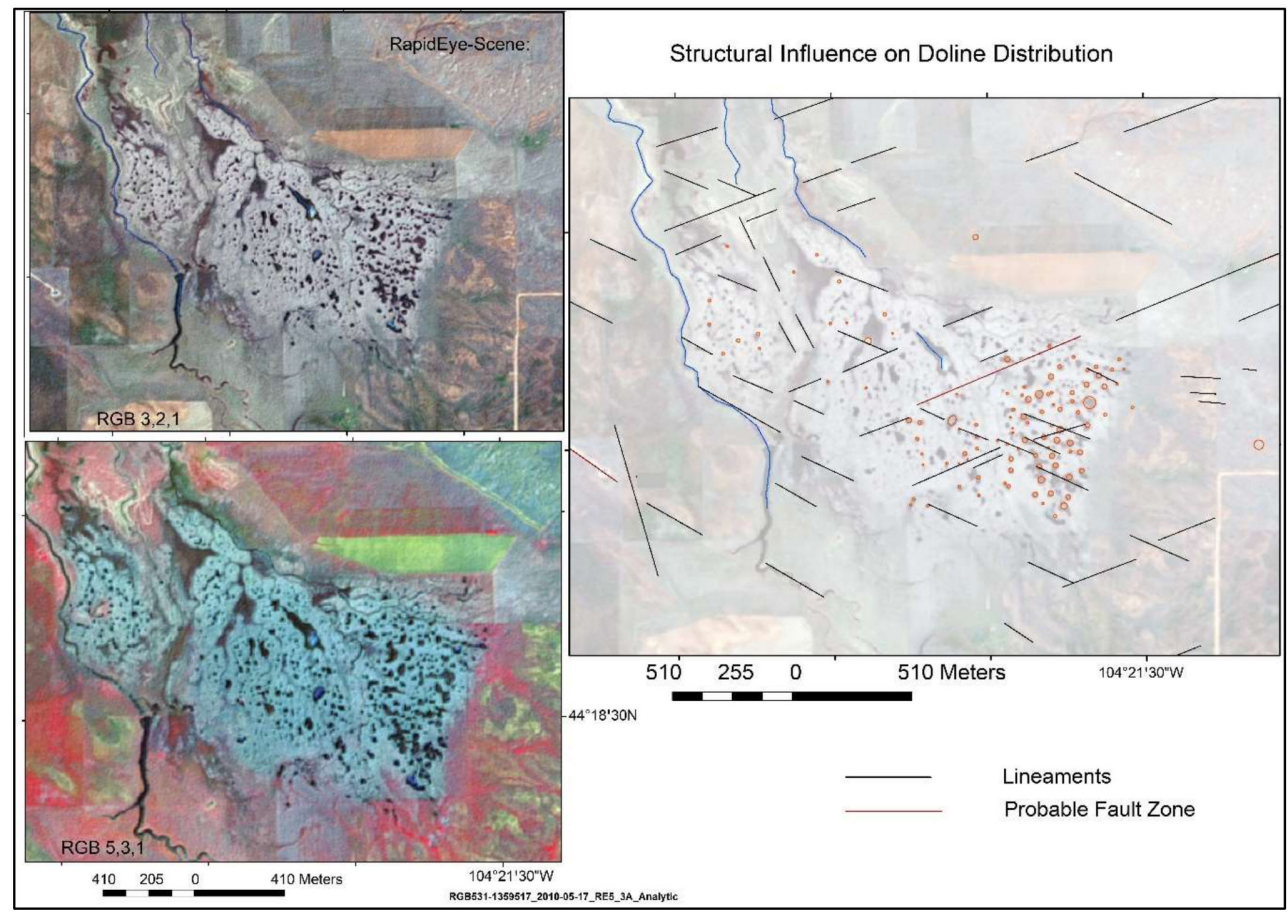

Figure 14. Linear, NW-SE oriented arrangements of dolines in depressions in the NW of the Black Hills.

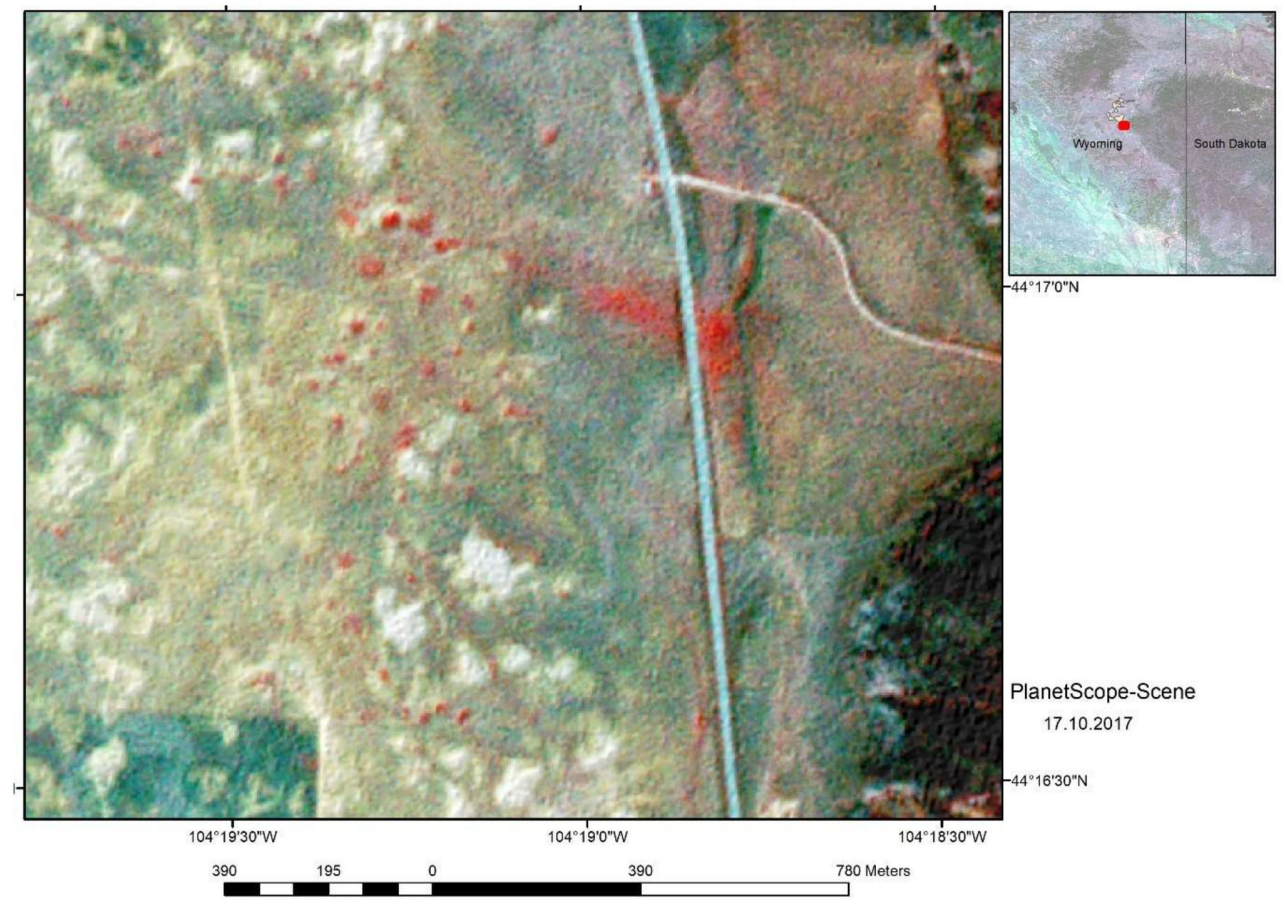

Figure 15. Doline fields visible on a PlanetScope-scene (RGB, Bands 5,3,1) showing vegetation with higher photosynthetic vitality (red colors).

The potential impact of climate change with increasing extreme weather events, some of them related to flash floods, might lead to increased water input to the ground within short time by accelerating dissolution and suffusion and increasing the weight of overlaying caprocks and sediments. This might lead to more cap rock collapse. 


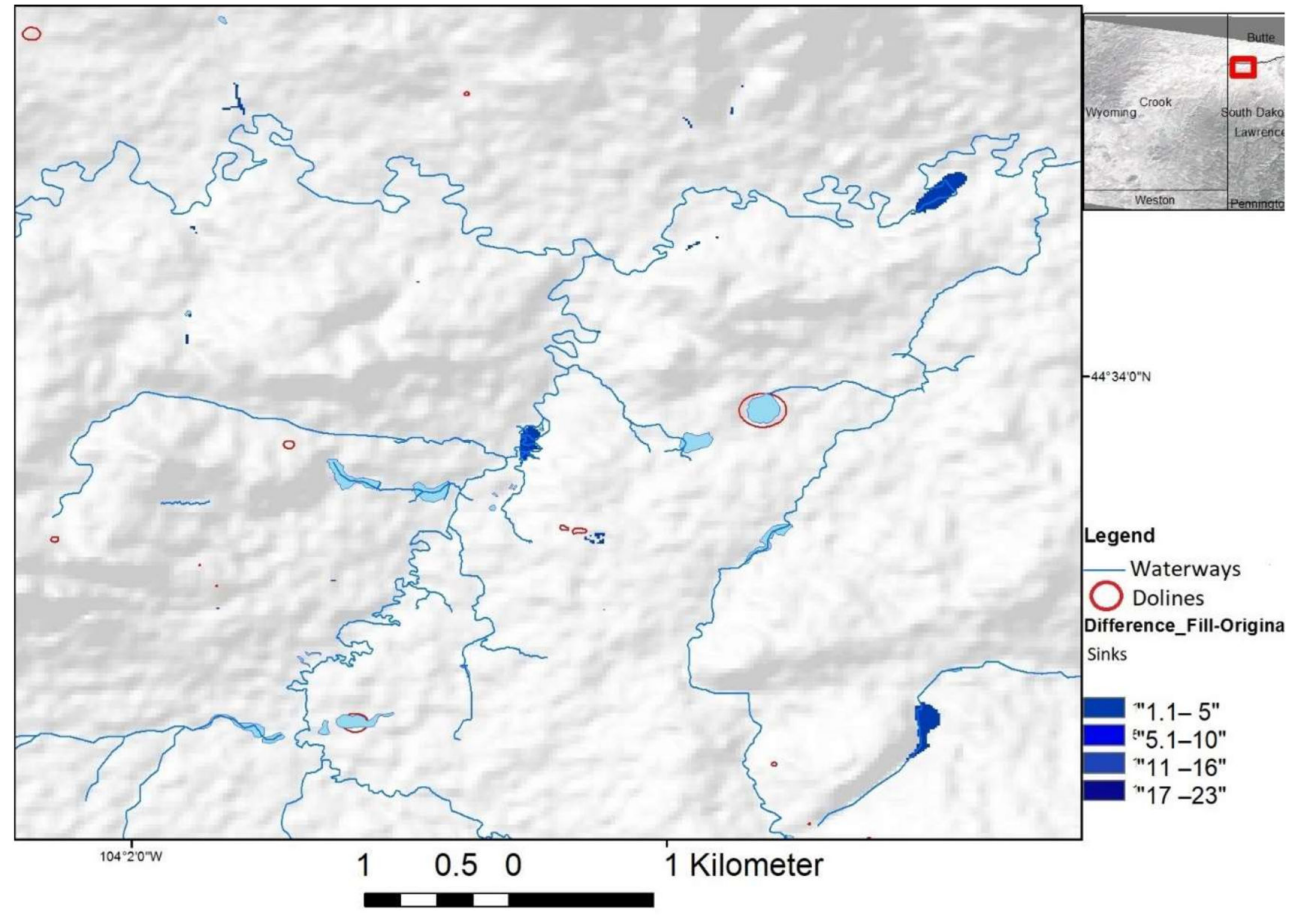

(a)

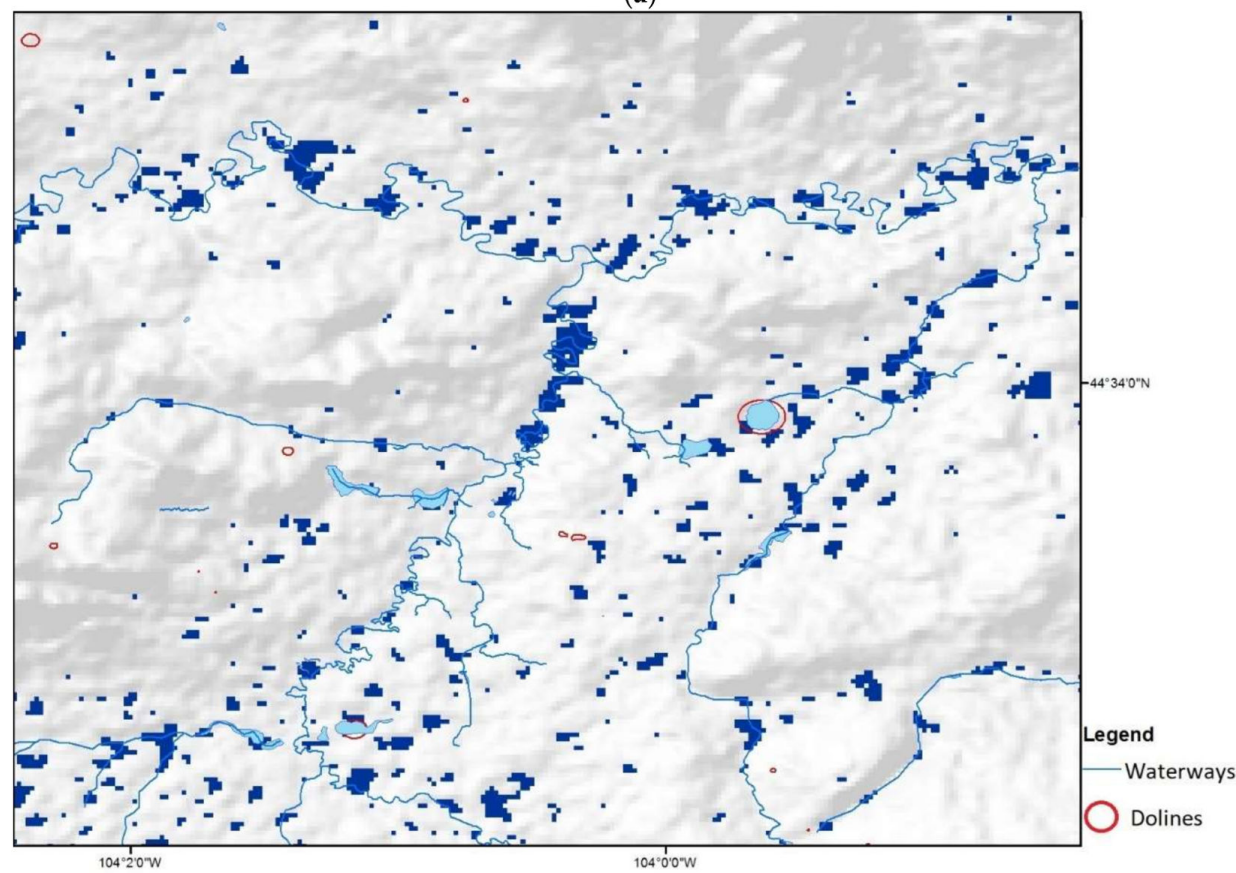

(b)

Figure 16. (a) (Visible number of sinks dark-blue) on the difference calculation: (Fill-ALOS-PALSARDEM)-(ALOS PALSAR-DEM); (b) (Visible sinks dark-blue) on the difference calculation: (Fill-SRTM)-(SRTM).

Doline fields occur predominently in basin/depression areas showing slope angles $<5^{\circ}$, terrain curvature $=0$, and the flow accumulation is concentrated as well as the drop flow (Figure 17). These areas are prone to flash floods during heavy rain fall and to higher infiltration of the surface water. 


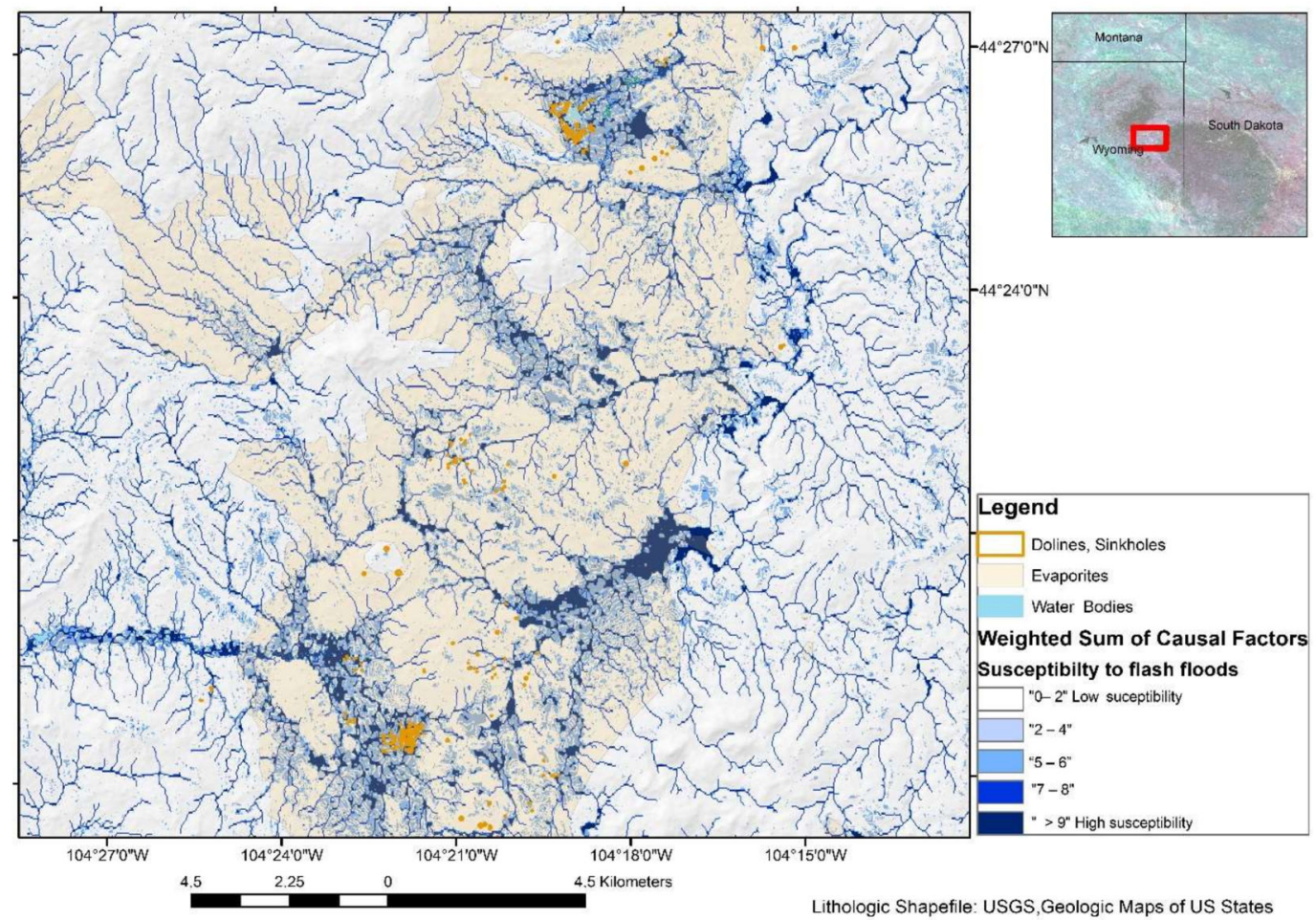

Figure 17. Weighted sum of causal, morphometric factors influencing surface water input and groundwater flow showing areas prone to higher surface water input in blue colors, doline fields occurring within broader valleys and depressions (visible in dark-blue, doline fields-red circle).

\section{Discussion and Conclusions}

Evaluations of different satellite data have contributed to the systematic inventory and mapping of surface-near karst features in the Black Hills area. When analyzing circular and oval-shaped forms visible on satellite images within lithologic units prone to karst development such as limestones, evaporites and dolostones, several types could be distinguished: larger circular features, enclosed depressions and sinkholes/dolines. The complex origin and development of the larger circular features will need further investigations for detailed clarification.

Enclosed depressions, partly with complex origin, are the prevailing forms within the karst prone lithologic units. After precipitation during the humid season, especially after flash floods, depressions are partly flooded. Dolines and depressions are filled then with surface water and form temporary ponds. As soil moisture is retained longer in sinkholes and depressions than in the flatter environment, the photosynthetic activity of vegetation is more intense, what leads to the visibility of circular depressions on satellite images. Thus, depressions can be detected on satellite images that are often not visible in the field during dryer seasons. Further on, wintertime images showing snow covers also support the delineation and mapping of the smaller, circular karst features.

Several doline fields were mapped at the northwestern and western margin of the Black Hills, situated within broader valleys and depressions. SRTM-, ASTER-, and ALOS POLSAR-DEM data provide morphometric information about these areas, as well as about the length and diameter of karst features as far as the spatial resolution of the satellite data allows their detection. By aggregating causal, morphometric factors influencing surface water input after precipitations the resulting maps of weighted overlay calculations contribute to a better understanding of the development of doline fields, focusing on the relatively lowest and flattest areas. The systematic, standardized approach according to the weighted overlay contributes to the detection of areas prone to flash floods and higher surface water input due to their morphometric disposition. Within karst-affected areas this approach helps to 
identify those areas where karstification processes might be more intense because of the higher water availability for rock dissolution.

Sentinel-1 and ALOS PALSAR radar images support the identification of the structural pattern of the Black Hills. The lineament analysis contributes to a better understanding of the influence of the structural pattern on karst development.

The study demonstrates that digital elevation models and high resolution satellite imagery produce the best results in karst geomorphological research when used in combination. The fused components complement each other and reduce their respective drawbacks [17].

When dealing with the impact of climate change on karst development in this area, long-term reliable observations on karst processes have still to be documented. It can be assumed, however, taking into consideration observations in other karst areas, that in case of intensified extreme weather events with flash floods, dissolution processes and doline collapse will be affected. Therefore, the areas susceptible to flash floods should be monitored continuously.

Supplementary Materials: The following are available online at http:/ /www.mdpi.com/2076-3263/8/6/192/s1.

Acknowledgments: This research was supported by the Planet Education and Research Program of Planet (Planet Team (2017). Planet Application Program Interface: In Space for Life on Earth. San Francisco, CA. (https:/ / api.planet.com) by providing RapidEye-scenes and PlanetScope-images of the Northern Black Hills, especially time series for change detection [18]. The author is very grateful for this support. The author thanks the reviewers and the editor for their helpful comments.

Conflicts of Interest: The author declares no conflict of interest. The sponsors had no role in the design of the study; in the collection, analyses, or interpretation of data; in the writing of the manuscript, and in the decision to publish the results.

\section{References}

1. Lisenbee, A.L.; Tectonic History of the Black Hills Uplift. Thirty-Ninth Field Conference Guidebook, Eastern Powder River Basin-Black Hills. Casper, Wyoming: Wyoming Geological Association, 1988. Available online: http:/ / pbadupws.nrc.gov/docs/ML1302/ML13023A327.pd (accessed on 29 March 2018).

2. Dewitt, E.; Redden, J.A.; Burack Wilson, A.; Buscher, D.; Dersch, J.S. Mineral Resource Potential and Geology of the Black Hills National Forest, South Dakota and Wyoming. U.S. Geological Survey Bulletin 1580; 1986. Available online: http:/ / pubs.usgs.gov/bul/1580/report.pdf (accessed on 15 November 2015).

3. Wicks, J.L.; Dean, S.L.; Kulander, B.R. Regional tectonics and fracture patterns in the Fall River Formation (Lower Cretaceous) around the Black Hills foreland uplift, western South Dakota and northeastern Wyoming. Geol. Soc. Lond. Spec. Publ. 1999, 169, 145-165. [CrossRef]

4. Hayes, T.S. Episodic Sediment-Discharge Events in Cascade Springs, Southern Black Hills, South Dakota. Water-Resources Investigations Report 99-4168, 1999; Prepared in Cooperation with the South Dakota Department of Environment and Natural Resources and the West Dakota Water Development District, U.S. Department of the Interior, U.S. Geological Survey, Rapid City. Available online: https:/ / pubs.usgs.gov / wri/wri994168/pdf/wrir99.4168.pdf (accessed on 30 March 2018).

5. Driscoll, D.G.; Janet, M.C.; Williamson, J.E.; Putnam, L.D. Hydrology of the Black Hills Area, South Dakota. Water-Resources Investigations Report 02-4094, 2002; U.S. Department of the Interior, U.S. Geological Survey, Prepared in Cooperation with the South Dakota Department of Environment and Natural Resources and the West Dakota Water Development District, Rapid City. Available online: https:/ / pubs.usgs.gov/wri/ wri024094/pdf/wri024094.pdf (accessed on 30 March 2018).

6. Stamm, J.F.; Poteet, M.F.; Symstad, A.J.; Musgrove, M.L.; Long, A.J.; Mahler, B.J.; Norton, P.A. Historical and Projected Climate (1901-2050) and Hydrologic Response of Karst Aquifers, and Species Vulnerability in South-central Texas and Western South Dakota. U.S. Geological Survey Scientific Investigations Report 2014-5089. 2015. Available online: http:/ / dx.doi.org/10.3133/sir20145089 (accessed on 12 February 2017).

7. EPA United States Environmental Protection Agency. What Climate Change Means for South Dakota. EPA 430-F-16-043. 2016. Available online: https://archive.org/details/climate-change-sd (accessed on 29 March 2018). 
8. Redden, J.A.; DeWitt, E. Maps Showing Geology, Structure, and Geophysics of the Central Black Hills, South Dakota. U.S. Geological Survey Scientific Investigations Map 2777. 44p, Pamphlet, 2 Sheets. Available online: http:/ / pubs.usgs.gov/sim/2777/downloads/2777_pamphlet_508.pdf (accessed on 30 March 2018).

9. Davis, A.D.; Beaver, F.W.; Stetler, L.D. Engineering Problems of Gypsum Karst along the Interstate 90 Development Corridor in the Black Hills of South Dakota. In: Johnson, K.S.; Neal, J.T. Evaporite Karst and Engineering/Environmental Problems in the United States. Oklahoma Geol. Surv. Circ. 2003, 109, 255-261. Available online: https://www.researchgate.net/profile/Kenneth_Johnson7/publication/286178657_ Evaporite-karst_problems_in_the_United_States/links/570bb64608ae2eb94223aae8/Evaporite-karstproblems-in-the-United-States.pdf (accessed on 30 March 2018).

10. Epstein, J.P.; Putnam, L.D. Introduction to Three Field Trip Guides: Karst Features in the Black Hills, Wyoming and South Dakota. Prepared for the Karst Interest Group Workshop, September 2005. Available online: https: / pubs.usgs.gov/sir/2005/5160/PDF/sir2005-5160part5.pdf (accessed on 30 March 2018).

11. Epstein, J.B. Hydrology, Hazards, and Geomorphic Development of Gypsum Karst in the Northern Black Hills, South Dakota and Wyoming. In: U.S. Geological Survey Karst Interest Group, Proceedings, Water-Resources Investigations Report 01-4011. Kuniansky, E.L., Ed.; 2001; pp. 30-37. Available online: https:// water.usgs.gov/ogw/karst/kigconference/pdffiles/jbe_hydrologyhazards.pdf (accessed on 30 March 2018).

12. Epstein, J.B.; Doctor, D.H. Evaporite Karst in the Black Hills, South Dakota and Wyoming, and the Oil Play in the Williston Basin, North Dakota and Montana. 13th Sinkhole Conference, 2012, NCKRI Symposium, 2. pp. 161-176. Available online: http:/ / www.infocastinc.com/downloads_pdf/bakken11_pre.pdf (accessed on 11 May 2012).

13. US Geological Survey, Geologic Shapefiles. Available online: https://mrdata.usgs.gov/geology/state/ (accessed on 30 March 2018).

14. Pardo-Igúzquiza, E.; Valsero, J.J.D.; Dowd, P.A. Automatic Detection and Delineation of Karst Terrain Depressions and Its Application in Geomorphological Mapping and Morphometric Analysis. ACTA CARSOLOGICA 2013, 42/1, 17-24, POSTOJNA. Available online: https:/ /ojs.zrc-sazu.si/carsologica/ article/view / 637 (accessed on 30 March 2018).

15. De Carvalho Júnior, O.A.; Guimarães, R.F.; Montgomery, D.R.; Gillespie, A.R.; Gomes, R.A.T.; de Souza Martins, E.; Correia Silva, N. Karst Depression Detection Using ASTER, ALOS/PRISM and SRTM-Derived Digital Elevation Models in the Bambuí Group, Brazil. Remote Sens. 2014, 6, 330-351. [CrossRef]

16. Theilen-Willige, B. Natural Hazard Assessment and Monitoring in the Black Hills and Adjacent Areas, South Dakota and Wyoming, USA, Using Remote Sensing and GIS-Methods. J. Geogr. Environ. Earth Sci. Int. 2016, 1-24. [CrossRef]

17. Siart, C.; Bubenzer, O. Bernhard Eitel Combining digital elevation data (SRTM/ASTER), high resolution satellite imagery (Quickbird) and GIS for geomorphological mapping: A multi-component case study on Mediterranean karst in Central Crete. Geomorphology 2009, 112, 106-121. [CrossRef]

18. Planet Team. Planet Application Program Interface: In Space for Life on Earth. San Francisco, CA. Available online: https: / /api.planet.com, https:/ / www.planet.com/markets/education-and-research/ (accessed on 22 April 2017).

(C) 2018 by the author. Licensee MDPI, Basel, Switzerland. This article is an open access article distributed under the terms and conditions of the Creative Commons Attribution (CC BY) license (http:/ / creativecommons.org/licenses/by/4.0/). 